\title{
PENINGKATAN HASIL DAN AKTIVITAS BELAJAR IPS MODEL PROBLEM-BASED LEARNING BERBANTUAN MEDIA SMPN 2 KAWUNGANTEN
}

\author{
Suharto, Zamroni \\ SMPN 2 Kawunganten Cilacap, Universitas Negeri Yogyakarta \\ suharto95@ymail.com, zamronihardjowirono@yahoo.com
}

\begin{abstract}
Abstrak
Penelitian ini bertujuan untuk (1) meningkatkan hasil dan (2) Aktivitas belajar IPS siswa kelas VIII C SMP Negeri 2 Kawunganten Cilacap. Penelitian ini merupakan penelitian tindakan kelas (PTK) yang terdiri atas empat pertemuan dalam dua siklus, menggunakan desain Kemmis \& Taggart. Subjek penelitian adalah 35 siswa kelas VIII C SMP Negeri 2 Kawunganten Cilacap. Teknik pengumpulan data yang digunakan adalah observasi, tes hasil belajar, angket, dokumentasi, dan catatan lapangan. Teknik analisis data menggunakan analisis deskriptif kuantitatif. Hasil penelitian adalah sebagai berikut: (1) Melalui model pembelajaran Problem-based learning berbantuan media dalam pembelajaran IPS dapat meningkatkan hasil belajar. (2) Ada peningkatan ketuntasan hasil belajar ranah kognitif. Pada siklus I ketuntasan belajar siswa 60,00\%, dan siklus II menjadi 85,71\%. (3) Ada peningkatan nilai sikap siswa (hasil belajar ranah afektif). Rata-rata nilai sikap siswa 62,20 pada siklus I menjadi 67,97 pada siklus II atau meningkat 5,77 poin. (4) Ada peningkatan aktivitas belajar siswa; siklus I rata-rata aktivitas belajar siswa 3,01 menjadi 3,37 pada siklus II, atau meningkat 0,36 poin.
\end{abstract}

Kata Kunci: model pembelajaran Problem-based learning, media pembelajaran, hasil belajar.

\section{IMPROVING LEARNING OUTCOME AND ACTIVITIES IN SOCIAL STUDIES OF THE MEDIA-AIDED PROBLEM-BASED LEARNING INSTRUCTIONAL MODEL SMPN 2 KAWUNGANTEN}

Suharto, Zamroni

SMPN 2 Kawunganten Cilacap, Universitas Negeri Yogyakarta suharto95@ymail.com, zamronihardjowirono@yahoo.com

\begin{abstract}
This study aims to: (1) improve the learning outcome and (2) activities of class VIII C, SMP Negeri 2 Kawunganten Cilacap. This study is classroom action research (CAR) consisting of two cycles, each of which consisted of two meetings, using Kemmis \& Taggart design. The subject is 35 students of class VIII C, SMP Negeri 2 Kawunganten Cilacap. The data collection techniques used were observation, achievement test, questionnaire, documentation, and field note. The data analysis used the quantitative descriptive analysis. The results are as follows (1) The through of media-aided Problem-Based Learning instructional model in social studies teaching can enchance learning outcomes. (2) There is an increasing mastery of cognitive learning outcome. In the first cycle, it became $60,00 \%$, and in the second cycle, it became $85.71 \%$. (3) There is an increase in students' attitude (affective domain of learning outcome). The average of students' attitude score was 62.20 in cycle I and it became 67.97 in cycle II, or an increase of 5.57 point. (4) There is an increase in students'learning activities; in the first cycle, the average score of students' activities was 3.01 and it became 3.37 in cycle II, or an increase of 0.36 point.
\end{abstract}

Keywords: Problem-Based Learing, instructional model, instructional media, learning outcome 


\section{Pendahuluan}

Hasil belajar siswa yang tercermin dalam angka atau nilai mata pelajaran mempunyai beberapa fungsi. Salah satu fungsi nilai hasil belajar sebagai data, informasi, dan petunjuk mengenai tingkat pengetahuan, pemahaman, dan penguasaan materi serta keterampilan siswa. Seorang guru dapat melakukan refleksi terhadap pembelajaran setelah menganalisis hasil belajar siswa. Perubahan dan perbaikan dalam pembelajaran bertujuan meningkatkan hasil belajar siswa pada materi ajar, SK atau KD tertentu. Perubahan dan perbaikan meliputi perencanaan pembelajaran, pengorganisasian materi ajar, pemilihan media, dan metode pembelajaran

Hasil belajar siswa mata pelajaran IPS kelas VIII SMP Negeri 2 Kawunganten Cilacap pada tahun pelajaran 2013/2014 belum memuaskan. Hasil belajar IPS secara klasikal relatif rendah. Rendahnya nilai hasil belajar diketahui setelah siswa mengerjakan Ujian Tengah Semester I. Siswa kelas VIII SMP Negeri 2 Kawunganten Cilacap berjumlah 216 orang, terbagi menjadi 6 kelas rombongan belajar (6 rombel; 8A, B, C, D, E, dan 8F). Sebagaimana tabel 1, di bawah ini;

Tabel 1. Rekapitulasi Nilai Hasil UjianTengah Semester I Tahun Pelajaran 2013/2014

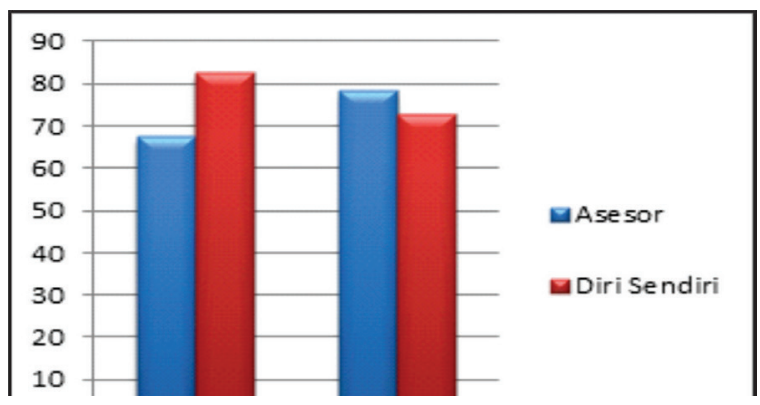

Sumber: Hasil UTS I tahun pelajaran 2013/2014. Dokumen guru IPS SMP N 2 Kawunganten.

Tabel 1 menunjukkan siswa yang tuntas KKM berjumlah 62 orang atau $28,84 \%$ dari 215 siswa dan siswa sebanyak 153 orang atau $71,16 \%$ belum tuntas. Ketuntasan belajar klasikal berkisar antara 22,22\% sampai dengan 33,33\%. Nilai siswa yang lulus KKM dengan jangkauan antara 72-93. Siswa yang mendapatkan nilai di atas nilai rata-rata kelas berjumlah 104 orang atau $48,37 \%$ dan siswa sebanyak 111 orang atau $51,63 \%$ berada di bawah nilai rata-rata kelas.
Adapun fokus penelitian pada upaya meningkatan hasil dan aktivitas belajar IPS siswa melalui penerapan model problem-based learning berbantuan media pembelajaran. Oleh karena itu masalah yang dibicarakan berkaitan dengan; (1) Seberapa besar peningkatan hasil belajar IPS siswa dapat ditingkatkan melalui penerapan model problem-based learning berbantuan media pembelajaran, (2) Seberapa besar peningkatan aktivitas siswa selama pembalajaran IPS dapat ditingkatkan melalui model problem-based learning berbantuan media pembelajaran.

Tujuan penelitian ini sebagai berikut: (1) Menganalisis peningkatan hasil belajar IPS siswa setelah guru menerapkan pembalajaran model problem-based learning berbantuan media pembelajaran. (2) mengetahui tingkat perubahan aktivitas siswa di kelas selama pembelajaran IPS melalui model problem-based learning berbantuan media pembelajaran.

Ilmu Pengetahuan Sosial (IPS) disebut juga sosial studies. "Social studies is the interdisiplinary integration of social science and humanities concepts for the purpose of practicing citizenship skills on critical social issues" (Barth, 1990, p.28). Pendapat tersebut bermakna, IPS merupakan perpaduan berbagai disiplin ilmuilmu sosial dan konsep-konsep humaniora dengan tujuan utama kemampuan praktis kewarganegaraan -seseorang atau masyarakatuntuk mengkritisi isu-isu sosial.

IPS merupakan salah satu mata pelajaran pada jenjang pendidikan dasar. IPS mengambil bahan-bahan dari ilmu-ilmu sosial diantaranya: geografi, sejarah, ekonomi, dan sosiologi. Sekalipun demikian, jumlah dan bagian isi ilmu sosial yang diperlukan dalam pembelajaran tidaklah sama kedalaman dan keluasan, karena harus disesuaikan dengan tujuan intruksional dan perkembangan mental siswa.

Hasil belajar siswa yang rendah pada mata pelajaran IPS atau SK/KD tertentu dapat berfungsi sebagai feed back bagi guru dan siswa pada proses belajar-mengajar. Dimyati dan Mudjiono (1999, pp. 250-251), menyatakan bahwa: "hasil belajar merupakan hal yang dapat dipandang dari dua sisi yaitu sisi siswa dan dari sisi guru". Pada sisi siswa, hasil belajar merupakan tingkat perkembangan mental yang lebih baik bila dibandingkan pada saat sebelum belajar. Tingkat perkembangan mental tersebut terwujud pada ranah kognitif, 
afektif, dan psikomotor. Sedangkan pada sisi guru, hasil belajar merupakan saat terseleksinya materi ajar, strategi, penggunaan media, dan metode dalam penyampaian pesan pembelajaran atau pendidikan kepada siswa.

\section{Menurut Prawira (2012, p.229), bahwa:}

Hasil belajar adalah penguasaan sejumlah pengetahuan dan sejumlah keterampilan baru dan sesuatu sikap baru ataupun memperkuat sesuatu yang telah dikuasai sebelumnya, termasuk pemahaman dan penguasaan nilainilai.

Sedangkan Kennedy (2006, p.3) menyatakan:

Learning outcomes are statements that specify what learners will know or be able to do as a result of a learning activity. Outcomes are usually expressed as knowledge, skills or attitudes.

Proses belajar-mengajar dikatakan berhasil jika sebagian besar siswa dapat menerima, memahami, dan mampu melakukan tindakan keterampilan sesuai dengan indikator dari tujuan pembelajaran yang ditetapkan. Tujuan pembelajaran adalah hasil belajar yang dimiliki oleh siswa. Hamalik (2012, p.30), mengemukakan: "hasil belajar adalah bila seseorang telah belajar akan terjadi perubahan tingkah laku pada orang tersebut, misalnya dari tidak tahu menjadi tahu, dan dari tidak mengerti menjadi mengerti".

Hasil belajar merupakan tingkat perkembangan mental siswa yang lebih baik bila dibandingkan pada saat sebelum belajar. Hasil belajar biasanya mencakup sejumlah pengetahuan, keterampilan, dan sikap siswa sebagai dampak berinteraksi dengan lingkungan belajar. Masing-masing jenis hasil belajar dapat diisi dengan bahan atau materi ajar yang telah ditetapkan dalam kurikulum. Gagne (1975, pp.65-66), membagi lima kelompok kapabilitas yang dipelajari, yakni; (1) informasi verbal, (2) keterampilan intelektual, (3) strategi kognitif, (4) sikap dan (5) keterampilan gerak. Kelima kapabilitas tersebut merupakan jenis tagihan (kompetensi) yang harus ditunjukkan oleh siswa selama dan sesudah pembelajaran.

Hasil belajar dapat disimpulkan sebagai serangkaian perubahan dan keterampilan yang dimiliki siswa setelah menerima pengalaman belajar dalam lingkungan belajar. Hasil belajar IPS adalah serangkaian kemampuan yang dimiliki oleh siswa setelah belajar dan menerima pengalaman sebagai dampak interaksi dengan lingkungan, sumber/materi ajar IPS.

Pembelajaran adalah aktivitas mengajar seorang guru dan aktivitas belajar yang dilakukan oleh sejumlah siswa. Aktivitas mengajar menyangkut peranan dan fungsi guru dalam mengupayakan terjalinnya proses interaksi dan komunikasi pembelajaran. Pembelajaran bukan hanya terbatas pada kejadian yang dilakukan oleh guru saja, melainkan mencakup semua kejadian maupun kegiatan yang mempunyai pengaruh langsung pada proses belajar siswa.

Guru hendaknya dapat memotivasi siswa agar aktivitas dalam pembelajaran dapat optimal. Sehingga proses belajar akan lebih dinamis dan menjamin setiap siswa memperoleh pengetahuan dan keterampilan. Aktivitas belajar merupakan fungsi siswa saat merespon stimulan yang disajikan oleh guru pada lingkungan belajar. Menurut Sardiman (2011, p.95) "belajar adalah berbuat, berbuat untuk mengubah tingkah laku, jadi melakukan kegiatan. Tidak ada belajar jika tidak ada aktivitas". Pendapat tersebut, bermakna bahwa dalam pembelajaran, belajar, dan aktivitas saling berhubungan sehingga proses pembelajaran berjalan optimal. Dengan kata lain, keterlibatan dan keberhasilan seorang siswa dalam aktivitas belajar tidak hanya ditentukan oleh kemampuan kecerdasannya, tetapi juga harus melibatkan fisik dan mental secara bersama-sama.

Proses belajar akan berlangsung efektif bilamana siswa terlibat secara aktif dalam setiap sesi pembelajaran dan berinteraksi dengan sumber daya belajar. Keterlibatan mental siswa dalam proses belajar sangat mempengaruhi terhadap aktivitas belajarnya. Seperangkat pengetahuan yang dibentuk melalui aktivitas sendiri pada seorang siswa akan lebih bermakna bagi diri siswa. Hal ini sebagaimana pendapat Chickering \& Gamson (2013, p.2):

..students must do more than just listen: They must read, write, discuss, or be engaged in solving problems. Most important, to be actively involved, students must engage in such higher-order thinking tasks as analysis, synthesis, and evaluation. Within this context, it is proposed that strategies promoting active learning be defined as 
instructional activities involving students in doing things and thinking about what they are doing.

Menurut pendapat Diedrich dalam Sardiman (2011, p.101), aktivitas belajar siswa dikelompokkan menjadi delapan yang meliputi: (1) Visual Aktivities (2) Oral Aktivities, (3) Listening Aktivities, (4) Writing Aktivities, (5) Drawing Aktivities, (6) Motor Aktivities, (7) Mental Aktivities, 8) Emotional Aktivities.

Belajar hanya mungkin terjadi apabila siswa aktif mengalaminya sendiri serangkaian tindakan. Keaktifan dapat berupa; (1) kegiatan fisik seperti membaca, mendengar, menulis dan sebagainya. (2) kegiatan psikis seperti mengunakan khazanah pengetahuan yang dimiliki dalam memecahkan masalah yang dihadapi, membandingkan konsep dengan yang lain, dan menyimpulkan hasil percobaan dan kegiatan psikis lainnya (Rusman, 2013, p.24)

Sebagaimana pendapat Eison $(2010$, p.1) bahwa:

Active learning instructional strategies can be created and used to engage students in 1) thinking critically or creatively, 2) speaking with a partner, in a small group, or with the entire class, 3) expressing ideas through writing, 4) exploring personal attitudes and values, 5) giving and receiving feedback, and 6) reflecting upon the learning process.

Maknanya adalah strategi pembelajaran aktif dirancang bertujuan untuk melibatkan siswa dalam (1) berpikir kritis atau kreatif, (2) berbicara dengan pasangan, dalam kelompok dengan kelompok, atau dengan seluruh kelas, (3) menyampaikan ide-ide melalui tulisan, (4) mengeksplorasi sikap pribadi dan nilai-nilai, (5) memberi dan menerima umpan balik, dan (6) merefleksikan proses pembelajaran.

Dari beberapa pendapat dapat disimpulkan aktivitas belajar merupakan serangkaian tindakan yang dilakukan siswa sebagai reaksi terhadap sejumlah stimulan dalam lingkungan pembelajaran. Setiap siswa dapat melibatkan kemampuannya semaksimal mungkin. Keterlibatan siswa secara aktif merupakan prinsip penting dalam pembelajaran. Aktivitas yang timbul dari siswa akan berdampak terbentuknya pengetahuan dan keterampilan yang mengarah kepada peningkatan hasil belajar.

Model pembelajaran yang dipilih dan diterapkan oleh Guru untuk pembelajaran IPS salah satunya adalah problem-based learning (pembelajaran berbasis-masalah). Problem-based learning $(P B L)$ mefokuskan pada pembelajaran siswa bukan pada pengajaran guru di kelas. Arends (2008, p.41) menyatakan, "peran guru dalam PBL hanya menyodorkan berbagai masalah autentik, memfasilitasi penyelidikan siswa, dan mendukung pembelajaran siswa". sedangkan pendapat Barr dan Tagg sebagaimana dikutip oleh Huda (2012, p.271), "PBL merupakan salah satu bentuk peralihan dari paradigma pengajaran menuju paradigma pembelajaran". Dengan kata lain, model PBL sebagai pembelajaran yang diperuntukkan bagi siswa menuju pemahaman akan suatu masalah.

Pembelajaran model PBL merupakan pembelajaran yang dimulai dengan pemberian "masalah" biasanya masalah tersebut memiliki konteks dengan dunia nyata, siswa secara berkelompok aktif merumuskan masalah dan melakukan identifikasi masalah. Mereka mempelajari dan mencari sendiri materi yang terkait dengan "masalah" dan melaporkan solusi dari "masalah". Hal ini sebagaimana dikemukakan oleh Arends \& Kilcher (2010, p.333);

Problem-based learning begin with the presentatioan of problem situation and the organisation of students into learning groups. Student groups are then asked to design and execute their investigations in pursuit of finding possible solutions. Students 'progress is monitored by the teacher and by student themselves as the inquiries unfold. Finally, groups demonstrate their learning and engage in reflection and debriefing.

Menurut pendapat Barrows dan Kelson dalam Amir (2009, p.21) bahwa:

problem-based learning (PBL) adalah kurikulum proses pembelajaran. Dalam kurikulumnya, dirancang masalah-masalah yang menuntut mahasiswa mendapat pengetahuan penting, membuatmerekamahir dalam memecahkan masalah, dan memiliki strategi belajar sendiri serta memiliki kecakapan berpartisipasi dalam tim. Proses belajarnya menggunakan pendekatan 


\section{yang sistemik untuk memecahkan masalah atau menghadapi tantangan yang nanti diperlukan dalam karier dan kehidupan sehari-hari.}

Pembelajaran model PBL menekankan siswa mampu menyelesaikan masalah secara sistematis. Model PBL merupakan pembelajaran yang diperoleh melalui proses menuju pemahaman akan resolusi suatu masalah. Artinya proses belajar berorientasi pada proses pengalaman langsung dari kehidupan sehari-hari siswa. Guru memberi kesempatan bagi siswa untuk aktif mencari, menemukan, mengolah, dan membentuk pengetahuan hasil belajarnya.

Keunggulan pembelajaran model PBL sangat berkaitan dengan langkah-langkah atau sintaks PBL itu sendiri. Adapun keunggulan pembelajaran model PBL terletak pada rancangan masalah yang disajikan oleh guru. Masalah yang diberikan harus menantang dan mendorong aktivitas siswa dalam belajar. Menurut Wee \& Kek dalam Amin, (2012, pp.32-33) menyatakan masalah yang baik bercirikan; (1). Punya keaslian seperti di dunia nyata. (2). Dibangun dengan memperhitungkan pengetahuan sebelumnya. (3). Membangun pemikiran yang metakognitif dan kontruktif. (4). Meningkatkan minat dan motivasi dalam pembelajaran. (5). Satuan Acara Perkuliahan (SAP) yang seharusny menjadi sasaran mata kuliah tetap dapat terliputi dengan baik.

Pendapat lain disampaikan oleh Barrows dan Tamblyn (Brock \& Jenkins, 2006, p.5) mengatakan bahwa keuntungan menggunakan model pembelajaran PBL yaitu: (1). Belajar cara belajar. (2). Belajar yang relevan untuk diri sendiri. (3). Menjadi peserta aktif dan termotivasi dalam proses belajar. (4). Belajar menjadi lebih puas. (5). Menilai kekuatan dan kelemahan diri sendiri dalam belajar. (6). Mengevaluasi diri dalam berpikir. (7). Merefleksikan kekuatan dan kelemahan diri sendiri. (8). Berpikir kritis. (9). Mengelola informasi. (10). Bekerja sama sebagai bagian dari kelompok. (11). Menggunakannya dalam praktek kesehatan.

Karakteristik problem-based learning (PBL) meliputi beberapa point penting sebagai berikut: (a) Permasalahan menjadi starting point dalam belajar, (b) Permasalahan yang diangkat adalah permasalahan yang ada di dunia nyata, (c) Permasalahan membutuhkan perspektif ganda (multiple perspective), (d) Permasalahan, menantang pengetahuan yang dimiliki oleh siswa, sikap, dan kompetensi dalam belajar, (e) Pemanfaatan sumber pengetahuan yang beragam, dan evaluasi sumber informasi, (f) Belajar adalah kolaborasi, komunikasi, dan kooperatif, (g) Pengembangan keterampilan inquiry dan pemecahan masalah dengan penguasaan pengetahuan untuk mencari solusi.

Pada penerapan model Problem-Based Learning, guru lebih banyak berperan sebagai fasilitator, motivator, mediator, dan pembimbing. Guru mengajukan masalah autentik atau mengorientasikan siswa kepada permasalahan nyata yang terjadi di lingkungan kehidupan siswa. Guru menyediakan pokok-pokok materiajar, membimbing dalam proses penyelidikan, memfasilitasi dialog antara siswa (diskusi), serta memberikan dukungan terhadap upaya meningkatkan temuan.

Media yang dibantukan dalam pembelajaran disebut media pembelajaran. Media pembelajaran yang dipakai pada proses belajarmengajar diharapkan mampu meningkatkan hasil belajar dan aktivitas siswa. Sebagaimana pendapat Hamalik yang dikutip oleh Arsyad, (2002, pp.15-16);

Pemakaian media pengajaran dalan proses belajar mengajar dapat membangkitkan keinginan dan minat yang baru, membangkitkan motivasi dan rangsangan kegiatan belajar, dan bahkan membawa pengaruh-pengaruh psikologis terhadap siswa...,media pengajaran juga dapat membantu siswa meningkatkan pemahaman, menyajikan data dengan menarik dan terpercaya, memudahkan penafsiran data, dan memadatkan informasi.

Media pembelajaran yang dipakai oleh guru dari bentuk sederhana sampai dengan bentuk modern. Media pembelajaran dapat berupa; gambar diam, gambar gerak, gambar gerak-bersuara (audio visual) dan dapat pula alat-alat peraga tiga dimensi serta bentuk-benda tiruan (model). Menurut Rossi dan Breidle sebagaimana dikutip oleh Sanjaya (2012, p.58) media pembelajaran adalah "seluruh alat dan bahan yang dapat dipakai untuk tujuan pendidikan seperti radio, televise, buku, koran, majalah dan sebagainya". Batasan ini lebih 
metitikberatkan pada sarana fisik yang digunakan untuk saluran komunikasi yang digunakan guru untuk menyampaikan pesan pembelajaran kepada siswa.

Lebih tegas Gerlach dan Ely dalam Sanjaya (2012, p.60), menyatakan "A medium, conceived any person, material or even that establish condition which enable the learner to acquicre knowledge, skill, and attitude".

Jadi dapat disimpulkan bahwa media pembelajaran adalah suatu sarana komunikasi dan interaksi antara guru dengan siswa dalam memperagakan suatu hal dan menvisualisasikan konsep tertentu dalam pembelajaran, dan membantu siswa mendapatkan informasi, pengetahuan, dan pemahaman serta pengalaman belajar yang lebih nyata.

Salah satu tujuan media pembelajaran adalah sebagai alat bantu yang turut mempengaruhi iklim belajar, kondisi, dan lingkungan belajar yang diciptakan guru baik di dalam maupun di luar kelas. Sebagaimana pendapat Gafur (2012, p.110), fungsi media secara umum sebagai berikut: (1). Memperjelas konsep (2). Menyederhanakan materi pelajaran yang kompleks (3). Menampakdekatkan yang jauh, menampakjauhkan yang dekat (4). Menampakbesarkan yang kecil, menampakkecilkan yang besar (5). Menampakcepatkan dan menampaklambatkan sebuah proses (6). Menampakgerakkan yang statis, menampakstatiskan yang gerak (7). Menampilkan suara dan warna sesuai dengan aslinya.

Bertolak dari pendapat tersebut, maka tujuan dan fungsi media adalah: (1) Memperjelas penyajian pesan, (2) Meningkatkan kegairahan belajar siswa dan mengatasi sikap pasif siswa, (3) Memberikan rangsangan dan persepsi siswa terhadap isi pelajaran, (4) Mengatasi keterbatasan ruang, waktu, dan daya indera.

Pemilihan media pembelajaran didasarkan atas pertanyaan yang berhubungan dengan tujuan pembelajaran, materi ajar, dan karakteristik media serta gaya belajar siswa. Pemilihan media pembelajaran yang digunakan harus sesuai dengan kebutuhan atau tujuan pembelajaran yang terikat oleh prinsip manfaat, ekonomis, mudah, dan bermutu.

Materi ajar yang dipilih dan ditetapkan dalam pembelajaran merupakan panduan serangkaian tindakan subjek ajar. Standar materi- ajar (keluasan dan kedalaman) berfungsi untuk mengukur kompetensi siswa dan kemajuan belajar. Materi-ajar dijadikan standar pencapaian maka haruslah menantang dan dapat diwujudkan oleh siswa maupun guru. Materi-ajar dapat diselesaikan dalam jangka waktu relatif singkat sehingga penilaian dapat dilakukan selama atau di akhir pertemuan kelas.

Materi ajar dan media pembelajaran yang disajikan secara bersamaan dalam pembelajaran dapat meningkatkan sikap, motivasi, dan aktivitas siswa. Penyajian materi ajar oleh guru akan lebih mudah dan bermakna bagi siswa jika dilengkapi dengan media pembelajaran yang sesuai. Siswa dalam menerima dan memahami pembelajaran lebih merasakan kenyataan sesungguhnya. Siswa dengan sendirinya terdorong pada pencapaian tujuan pembelajaran. Namun sejauh ini keberhasilan model PBL belum pernah dilaksanakan dengan berbantuan media kreatif untuk peningkatan hasil belajar siswa.

Melangkah dari beberapa hasil penelitian mengenai model problem-based learning dan penggunaan media pembelajaran, dapat ditarik kesimpulan; (1) ada peningkatan hasil belajar siswa. (2) ada peningkatan aktivitas belajar siswa. (3) berpikir kritis dan penguasaan materi oleh siswa lebih baik. (4) mempermudah, memperjelas, dan mengefektifkan penguasaan kompetensi oleh siswa.

Berdasar kajian teoritis dan hasil kajian yang relevan, penelitian tindakan kelas diharapkan mampu meningkatkan hasil dan aktivitas belajar IPS siswa SMP Negeri 2 Kawunganten Cilacap. Peningkatan hasil dan aktivitas belajar IPS siswa dapat dicapai melalui model PBL berbantuan media pembelajaran yang sesuai dengan kompetensi dasar.

Perubahan dan perbaikan terhadap metode pembelajaran IPS melalui penerapan model problem-based learning berbantuan media. Model PBL berbantuan media dapat meningkatkan proses interaksi dan komunikasi pembelajaran antara guru dengan siswa, siswa dengan siswa, dan siswa dengan lingkungan masalah, serta meningkatkan kemampuan berfikir kritis, inquiri, dan kontruktif. Dengan demikian, model PBL berbantuan media diharapkan dapat meningkatkan aktivitas dan sikap siswa dalam pembelajaran yang pada akhirnya meningkatkan hasil belajar IPS secara komprehensif. 


\section{Metode Penelitian}

Desain penelitian yang digunakan adalah model Kemmis \& Mc. Taggart (1990, p.11), desain alur penelitian model spiral yang terdiri atas 3 (tiga) komponen yaitu: perencanaan, tindakan dan observasi, dan refleksi (plan, action and observe, and reflect).

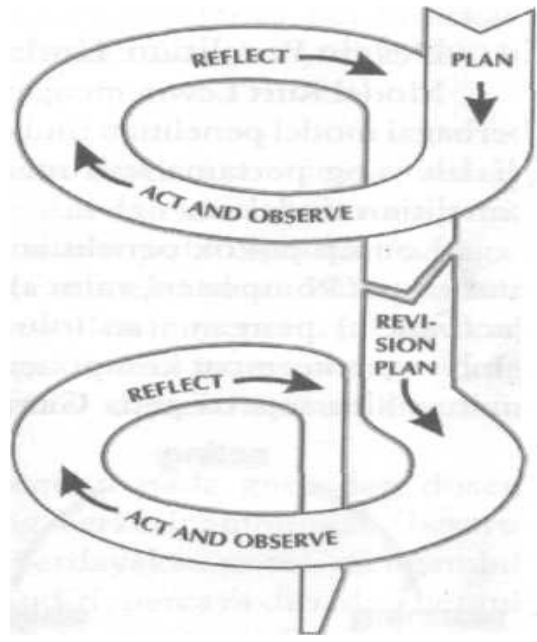

Gambar 1. Alur Penelitian Model Spiral Kemmis \& Mc.Taggart (1990: 11).

Model tersebut mengandung prinsip kontinuitas dan fleksibitas, artinya jika pada pelaksanaan tindakan siklus pertama ditemukan kekurangan atau kelemahan maka harus dilakukan tindakan perbaikan pada siklus selanjutnya sampai target yang diinginkan atau diharapkan tercapai.

Tahapan siklus dari rencana tindakan sampai dengan refleksi yang dilakukan sebagai berikut:

\section{Perencanaan.}

Tahap awal, menjajaki keadaan lingkungan kelas, sikap siswa terhadap pembelajaran, dan aktivitas siswa dalam pembelajaran IPS melalui observasi.

\section{Pelaksanaan Tindakan dan Observasi.}

Pada tahap ini, melaksanakan pembelajaran IPS dengan mengintegrasikan model problembased learning berbantuan media gambar-diam yang sesuai kompetensi. Media pembelajaran (gambar-diam) yang dipakai bertujuan menarik perhatian, memberikan kemudahan, memperjelas materi ajar dan menghindari kesalahpahaman penerimaan pesan pembelajaran.
Pengamatan secara cermat dan sistematis terhadap proses dan hasil belajar-mengajar guru dan siswa. Kegiatan pengamatan ini dilakukan dengan alat bantu berupa instrumen pedoman observasi untuk siswa serta catatan pengamatan untuk merekam aktivitas siswa dalam setiap siklus.

\section{Refleksi.}

Hasil observasi dikumpulkan kemudian dianalisis dan dievaluasi. hasil ini sebagai acuhan refleksi untuk melihat apakah tindakan yang dilakukan sebelumnya sudah memenuhi harapan atau mendekati tujuan yang ditetapkan. Refleksi merupakan tahapan yang sangat penting dalam penelitian ini dimana perubahan dan perbaikkan ditentukan. Apabila refleksi belum sesuai harapan ataupun tujuan maka akan ditempuh tindakan untuk penyempurnaan pada siklus berikutnya sehingga diperoleh hasil yang yang diharapkan.

\section{Rencana Revisi.}

Tahapan penyusunan perubahan rencana melangkah dari kelemahan-kelemahan yang terjadi pada tindakan siklus I setelah dilakukan refleksi. Beberapa alternatif perubahan dan pelaksanaan tindak perbaikkan yang diyakini mampu meningkatkan hasil dan aktivitas belajar siswa dilakukan oleh guru untuk mencapai kriteria keberhasilan pembelajaran dan/atau penelitian.

Penelitian ini dilaksanakan dari bulan Oktober sampai dengan bulan Desember tahun 2013 atau selama 3 bulan pada tahun pelajaran 2013/2014. Sedangkan tempat penelitian adalah SMP Negeri 2 Kawunganten Cilacap, beralamat di jalan Raya Karangbawang Kawunganten, Kecamatan Kawunganten Kab. Cilacap. SMP Negeri 2 Kawunganten Cilacap mempunyai rombongan belajar 18 kelas yang terbagi menjadi 3 (tiga) tingkatan yaitu kelas VII, VIII, dan IX. Setiap tingkatan kelas terdiri dari 6 rombongan belajar.

Penelitian Tindakan Kelas ini dilakukan pada kelas VIII C SMP Negeri 2 Kawunganten Cilacap. Pemilihan kelas VIII C sebagai subyek penilitian dengan alasan hasil belajar Mapel IPS pada ulangan tengah semester I paling flukturatif dibandingkan dengan kelas VIII lainnya. Siswa kelas VIII C berjumlah 35 orang, terdiri dari siswa laki-laki 15 dan siswa perempuan 20 orang. Jadi seks rationya sebesar $75 \%$. Pada sisi 
usia, siswa kelas VIII C termasuk kelompok usia remaja awal yaitu; 12-15 tahun.

\section{Observasi}

Pedoman observasi dapat disusun dalam bentuk skala, adanya rentang nilai. Skala ini dapat berbentuk skala deskriptif. Peneliti menyiapkan pedoman observasi yang berisikan garis-garis besar atau butir-butir umum kegiatan yang akan diobservasi.

\section{Dokumentasi,}

Merupakan suatu teknik pengumpulan data dengan menghimpun dan menganalisis dokumen-dokumen, baik dokumen tertulis, gambar maupun elektronik. Dokumen-dokumen tersebut dipilih sesuai dengan tujuan dan fokus masalah serta diurutkan sesuai dengan sejarah kelahiran, kekuatan, dan kesesuaian isinya dengan tujuan pengkajian

Angket atau kuesioner,

Angket berisikan sejumlah pernyataan dan pertanyaan yang harus dijawab oleh responden. Instrumen/alat pengumpulan data secara tidak langsung disebut angket atau kuesioner.

\begin{tabular}{|c|l|c|c|c|c|c|}
\hline \multirow{2}{*}{ No } & \multirow{2}{*}{ Kegiatan Kelas } & \multicolumn{3}{|c|}{ Jumlah Skor } & \multirow{2}{*}{ Rerata } \\
\hline & & 1 & 2 & 3 & 4 & nilai \\
\hline 1 & Siswa mengamati & & & & & \\
\hline 2 & Siswa menyimak & & & & & \\
\hline 3 & Siswa mendengarkan & & & & & \\
\hline 4 & Siswa aktif bertanya & & & & & \\
\hline 5 & $\begin{array}{l}\text { Siswa aktif } \\
\text { menjawab }\end{array}$ & & & & & \\
\hline 6 & $\begin{array}{l}\text { Siswa berpartisipasi } \\
\text { dalam diskusi }\end{array}$ & & & & & \\
\hline 7 & $\begin{array}{l}\text { Siswa mencatat poin- } \\
\text { penting }\end{array}$ & & & & \\
\hline 8 & $\begin{array}{l}\text { Siswa ikut dalam } \\
\text { pengambilan } \\
\text { kesimpulan }\end{array}$ & & & & & \\
\hline 9 & $\begin{array}{l}\text { Siswa antusias dalam } \\
\text { pembelajaran }\end{array}$ & & & & & \\
\hline Jumlah Skor & & & & & \\
\hline Skor Rata-Rata & & & & & \\
\hline Klasifikasi & & & & & \\
\hline
\end{tabular}

Skor Aspek yang Diamati:
1 = Tidak Pernah
$3=$ Sering
$2=$ Jarang
4 = Selalu

\section{Kriteria Penilaian Ketercapaian}

\begin{tabular}{|c|c|c|}
\hline Skor & Rerata Skor & Klasifikasi \\
\hline$>31-36$ & $>3,40-4,00$ & Sangat Tinggi \\
\hline$>25-31$ & $>2,80-3,40$ & Tinggi \\
\hline$>19-25$ & $>2,20-2,80$ & Sedang \\
\hline$>13-19$ & $>1,60-2,20$ & Rendah \\
\hline$\leq 9-13$ & $\leq 1,60$ & Sangat Rendah \\
\hline
\end{tabular}

Tes hasil Belajar.

Teknik pengumpulan data ini digunakan untuk mengetahui tingkat keberhasilan pembelajaran terutama tentang hasil belajar siswa yang berhubungan dengan materi-materi yang telah dipelajari dengan penerapan model PBL berbantuan media pembelajaran. Kisikisi dan butir soal sebelum digunakan terlebih dahulu dilakukan validasi oleh ahli dibidangnya sehingga menghasilkan tes yang valid.

\section{Kisi-Kisi Instrumen Tes Hasil Belajar IPS}

\begin{tabular}{|c|c|c|c|c|c|c|c|}
\hline \multirow{3}{*}{$\begin{array}{l}\text { INDI- } \\
\text { KATOR }\end{array}$} & \multicolumn{5}{|c|}{$\begin{array}{l}\text { Aspek Intelektual } \\
\text { (Kognitif) }\end{array}$} & \multirow{2}{*}{\multicolumn{2}{|c|}{$\begin{array}{l}\text { Jml } \\
\text { Soal }\end{array}$}} \\
\hline & \multicolumn{5}{|c|}{ No Soal } & & \\
\hline & $\mathrm{C} 1$ & $\mathrm{C} 2$ & $\mathrm{C} 3$ & $\mathrm{C} 4$ & $\mathrm{C} 5$ & C6 & \\
\hline $\begin{array}{l}\text { Mendis- } \\
\text { kripsikan } \\
\text { pelaku } \\
\text { ekonomi }\end{array}$ & & $\begin{array}{l}1, \\
2 \\
4\end{array}$ & 5 & 3 & & & 5 \\
\hline $\begin{array}{c}\text { BUMN/D } \\
\text { dan } \\
\text { Koperasi }\end{array}$ & & 6 & $\begin{array}{l}7, \\
8\end{array}$ & & & & 3 \\
\hline $\begin{array}{c}\text { Peranan } \\
\text { RT K, RTP, } \\
\text { Pemerintah }\end{array}$ & 9 & & 10 & & & & 2 \\
\hline $\begin{array}{c}\text { Faktor } \\
\text { produksi } \\
\text { dan balas } \\
\text { jasa }\end{array}$ & & 11 & 13 & 12 & & & 3 \\
\hline $\begin{array}{l}\text { Kegiatan } \\
\text { pelaku } \\
\text { ekonomi }\end{array}$ & & & 14 & & & & 1 \\
\hline $\begin{array}{c}\text { Melacak } \\
\text { aktivitas } \\
\text { pelaku } \\
\text { ekonomi }\end{array}$ & & 15 & & & & & 1 \\
\hline JUMLAH & 1 & 6 & 6 & 2 & & & 15 \\
\hline
\end{tabular}


Analisis data dalam penelitian ini mereflesksi hasil observasi aktivitas siswa, aktivitas guru, dan penilaian hasil belajar siswa. Analisis meliputi perencanaan, pelaksanaan tindakan, observasi, dan reflesksi. Sedaangkan nilai hasil belajar (tes) merupakan data proses bagi peneliti dan/atau guru kolaborator. Kegiatan analisis dimulai dari menghitung, menggabungkan, dan mengorganisasikan data sesuai dengan derajat kepercayaan. Pengujian derajat kepercayaan dalam penelitian tindakan dapat berupa bentuk validasi. Melakukan validasi yaitu memeriksa kebenaran hipotesis, kontruk atau analisis isi dari peneliti dengan membandingkan hasil dari mitra peneliti atau kolaborator.

Analisis secara deskriptif dengan menggunakan teknik persentase untuk melihat kecenderungan yang terjadi dan peningkatan hasil belajar dan aktivitas siswa dalam pembelajaran. Hasil belajar siswa diperoleh melalui penilaian ulangan harian (tes formatif) siswa setiap akhir siklus. Perhitungan data menghasilkan nilai persentase pencapaian hasil belajar yang selanjutnya diinterprestasikan dalam kalimat bersifat kualitatif.

Kriteria keberhasilan dalam penelitian tindakan kelas ini secara kualilatif dan kuantitatif. Indikator kualitatif jika sebagian besar siswa menunjukkan aktivitas belajar lebih baik, adanya peningkatan selama tindakan penelitian. Siswa berani berpendapat, menjawab pertanyaan, bertanya, dan melakukan kegiatan penyelidikan suatu masalah serta mampu mengkomunikasikan hasil dalam kelompok maupun kelas.

\begin{tabular}{|c|c|c|c|c|}
\hline Uraian & Nilai & $\begin{array}{c}\text { Jumlah } \\
\text { Siswa }\end{array}$ & $\begin{array}{c}\text { Persen- } \\
\text { tase (\%) }\end{array}$ & Ket. \\
\hline Nilai Tertinggi & 87 & 5 & 14,78 & Tuntas \\
\hline Nilai Terendah & 53 & 5 & 14,78 & $\begin{array}{c}\text { Belum } \\
\text { tuntas }\end{array}$ \\
\hline Nilai Rata-rata & 69 & & & $\begin{array}{c}\text { Di atas } \\
\text { KKM }\end{array}$ \\
\hline Nilai $\geq$ KKM & & 21 & 60,00 & \\
\hline Nilai < KKM & & 14 & 40,00 & \\
\hline
\end{tabular}

Target keberhasilan dalam penelitian ini adalah peningkatan hasil belajar siswa dengan melihat ketuntasan belajar siswa secara individual dan klasikal. Siswa dikatakan tuntas bila memenuhi nilai $\mathrm{KKM} \geq 68$ dan secara klasikal memenuhi kriteria ketuntasan minimal $75 \%$.

\section{Hasil Penelitian dan Pembahasan}

Berdasarkan hasil analisis tindakan siklus I dan siklus II diperoleh peningkatan hasil belajar siswa melalui pembelajaran model PBL berbantuan media. Peningkatan hasil belajar siswa sejalan dengan kemampuan guru yang semakin baik dalam menerapkan pembelajaran model PBL berbantuan media pembelajaran yang lebih konkret. Perubahan dan peningkatan hasil belajar siswa terjadi setelah guru melakukan refleksi terhadap tindakan siklus I. Beberapa kekurangan dan kelemahan tindakan siklus I yang terjadi dicatat, diklasifikasikan, dan dianalisis untuk menentukan alternatif-alternatif solusi untuk perbaikkan pada tindakan siklus II. Kekurangan dan kelemahan meliputi aspek siswa, media dan metode pembelajaran yang dilakukan guru.

Pada tindakan siklus I, guru memberi arahan/bimbingan kepada siswa kurang maksimal terutama langkah-langkah pembelajaran model PBL. Siswa merasa asing dan tidak sepenuhnya dapat menerima atau memahami metode pembelajaran yang diterapkan. Langkah-langkah (sintaks) model PBL sebagai hal baru bagi siswa dan membutuhkan serangkaian penyesusaian perilaku siswa berkaitan dengan orang lain (kontak sosial dalam kelompok-kelompok diskusi).

Media pembelajaran berupa skema hubungan pelaku-pelaku ekonomi yang dipakai untuk menjelaskan materi ajar kurang konkret. Siswa mengalami kesulitan untuk memahami dan menganalisis isi materi. Skema hubungan pelaku ekonomi tidak dapat dipahami dengan sekali pengamatan. Materi pelaku-pelaku ekonomi terindikasi berkompleksitas tinggi. Guru harus melakukan apresepsi lebih banyak dan memberikan contoh konkret pelakupelaku ekonomi dalam masyarakat. Pemilihan dan menggunakan media pembelajaran yang berhubungan dengan materi pelaku ekonomi perlu adanya modifikasi oleh guru. 
Tabel 1. Rekapitulasi Nilai Hasil Belajar Siswa Pada Tindakan Siklus I

Tabel 2. Hasil Observasi Aktivitas Belajar Siswa Pada Siklus I

\begin{tabular}{|c|c|c|c|c|}
\hline No & $\begin{array}{c}\text { Rentang } \\
\text { Skor }\end{array}$ & Kategori & $\begin{array}{c}\text { Jumlah } \\
\text { siswa }\end{array}$ & $\begin{array}{c}\text { Persen- } \\
\text { tase (\%) }\end{array}$ \\
\hline 1 & $>32,6-36,0$ & $\begin{array}{c}\text { Sangat } \\
\text { baik }\end{array}$ & & \\
\hline 2 & $>28,2-32,6$ & Baik & 12 & 34,29 \\
\hline 3 & $>21,8-28,2$ & Cukup & 14 & 40,00 \\
\hline 4 & $>15,4-21,8$ & Kurang & 9 & 25,71 \\
\hline 5 & $\leq 9,0-15,4$ & $\begin{array}{c}\text { Sangat } \\
\text { kurang }\end{array}$ & & \\
\hline
\end{tabular}

Pada tindakan siklus II, Guru memberikan arahan/bimbingan kepada siswa sesuai dengan Siswa mengalami kemajuan belajar yang baik. Adanya peningkatan aktivitas siswa dan hasil belajar siswa. Pergerakkan nilai tertinggi, nilai terendah, dan nilai rata-rata kelas pada siklus I dan siklus II adalah baik. Sebagaimana tabel 5 dibawah ini.

pembelajaran model PBL. Langkahlangkah pembelajaran model PBL yang membutuhkan serangkaian perilaku siswa berkaitan dengan orang lain sudah dapat dilaksanakan dengan efektif. Banyak siswa dapat menerima dan memahami isi materi ajar sepenuh.

Media pembelajaran, berupa gambargambar pasar tradisional dan modern yang dipakai pada materi ajar pasar sangat konkret (contoh nyata mudah ditemukan) dan siswa dapat memahami dan menganalisis. Gambar-gambar pasar tradisional dan modern dapat disinkonkan dengan kenyataan dalam kehidupan. siswa mempunyai pengetahuan lengkap tentang materi pasar sesuai pengalaman diri masing-masing.

Tabel 3.Hasil Observasi Aktivitas Belajar Siswa Pada Siklus II

\begin{tabular}{|c|c|c|c|c|}
\hline No & $\begin{array}{c}\text { Rentang } \\
\text { Skor }\end{array}$ & Kategori & $\begin{array}{c}\text { Jumlah } \\
\text { siswa }\end{array}$ & $\begin{array}{c}\text { Persen-tase } \\
(\%)\end{array}$ \\
\hline 1 & $>32,6-36,0$ & $\begin{array}{c}\text { Sangat } \\
\text { baik }\end{array}$ & 7 & 20,00 \\
\hline 2 & $>28,2-32,6$ & Baik & 18 & 51,43 \\
\hline 3 & $>21,8-28,2$ & Cukup & 10 & 28,57 \\
\hline 4 & $>15,4-21,8$ & Kurang & & \\
\hline 5 & $\leq 9,0-15,4$ & $\begin{array}{c}\text { Sangat } \\
\text { kurang }\end{array}$ & & \\
\hline
\end{tabular}

Tabel 4. Rekapitulasi Nilai Hasil Belajar Siswa Pada Tindakan Siklus II

\begin{tabular}{|c|c|c|c|c|}
\hline Uraian & Nilai & $\begin{array}{c}\text { Jumlah } \\
\text { Siswa }\end{array}$ & $\begin{array}{c}\text { Persen- } \\
\text { tase (\%) }\end{array}$ & Ket. \\
\hline $\begin{array}{c}\text { Nilai } \\
\text { Tertinggi }\end{array}$ & 93 & 12 & 32,00 & Tuntas \\
\hline $\begin{array}{c}\text { Nilai } \\
\text { Terendah }\end{array}$ & 67 & 5 & 14,78 & $\begin{array}{c}\text { Belum } \\
\text { Tuntas }\end{array}$ \\
\hline $\begin{array}{c}\text { Nilai } \\
\text { Rata-rata }\end{array}$ & 77 & 30 & 85.71 & Di atas \\
\hline $\begin{array}{c}\text { Nilai } \\
\text { KKM }\end{array}$ & & 5 & & \\
\hline $\begin{array}{c}\text { Nilai } \\
\text { KKM }\end{array}$ & & & 14,29 & \\
\hline
\end{tabular}

Tabel 5. Rekapitulasi Hasil Belajar Siswa pada Pratindakan, Siklus I dan II.

\begin{tabular}{|c|c|c|c|c|}
\hline \multirow{2}{*}{ Uraian } & \multirow[b]{2}{*}{$\begin{array}{l}\text { Pratin- } \\
\text { dakan }\end{array}$} & \multicolumn{2}{|c|}{ Tindakan } & \multirow{2}{*}{$\begin{array}{c}\text { Nilai } \\
\text { Rata-rata } \\
\text { Tindakan }\end{array}$} \\
\hline & & $\begin{array}{c}\text { Siklus } \\
\text { I }\end{array}$ & $\begin{array}{c}\text { Siklus } \\
\text { II } \\
\end{array}$ & \\
\hline $\begin{array}{c}\text { Nilai } \\
\text { Tertinggi }\end{array}$ & 93 & 87 & 93 & 90 \\
\hline $\begin{array}{c}\text { Nilai } \\
\text { Terendah }\end{array}$ & 42 & 53 & 67 & 60 \\
\hline $\begin{array}{l}\text { Nilai Rata- } \\
\text { rata }\end{array}$ & 61 & 69 & 77 & 73 \\
\hline $\begin{array}{l}\text { Nilai } \geq \\
\text { KKM }\end{array}$ & $\begin{array}{c}9 \\
\text { orang }\end{array}$ & $\begin{array}{c}21 \\
\text { orang }\end{array}$ & $\begin{array}{c}30 \\
\text { orang }\end{array}$ & \\
\hline $\begin{array}{l}\text { Nilai < } \\
\text { KKM }\end{array}$ & $\begin{array}{c}26 \\
\text { orang }\end{array}$ & $\begin{array}{c}14 \\
\text { orang }\end{array}$ & $\begin{array}{c}5 \\
\text { orang }\end{array}$ & \\
\hline
\end{tabular}

Melangkah dari tabel tersebut, peningkatan hasil belajar siswa secara klasikal (rata-rata kelas) dari 69 menjadi 77, nilai terendah dari 53 menjadi 67, dan nilai tertinggi dari 87 menjadi 93. Perolehan nilai hasil belajar siswa pada tindakan siklus I dan tindakan siklus II, mengalami perbaikan secara individual maupun klasikal. Perbaikkan tersebut meliputi penyebaran nilai hasil belajar yang semakin merata. Hal ini terlihat dengan semakin kecilnya selisih nilai tertinggi dan nilai terendah pada siklus II daripada siklus I. Walaupun pada siklus II masih ada 5 orang siswa yang belum tuntas (14\%), tetapi pembelajaran yang dilakukan guru sudah baik. Persentase ketuntasan belajar siswa secara individual maupun klasikal sudah memenuhi harapan guru dan peneliti. Tabel 5 dapat dibuat grafik batang sebagai berikut; 


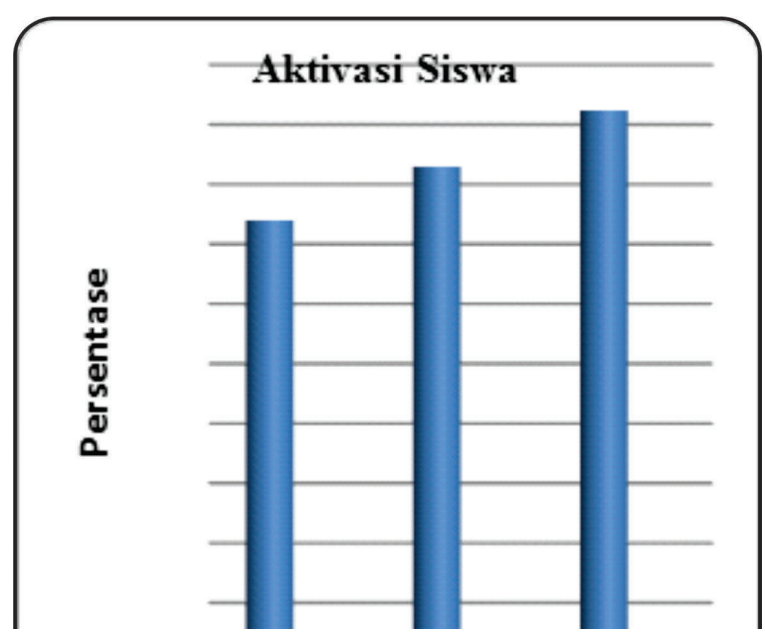

Gambar 2. Hasil Belajar Siswa Pada Pratindakan, Siklus I dan Siklus II.

Bila dibandingkan dengan standar besaran KKM Mapel IPS (68) dan kriteria belajar tuntas, sebagaimana pendapat Usman dan Setiawati (1993: 8) atau Djamarah (2006: 121) maka pelaksanaan tindakan selama penelitian ini telah berhasil dan pembelajaran yang dilakukan guru adalah baik optimal. Kriteria baik optimal untuk hasil belajar siswa adalah 76\%-99\%, sedangkan hasil belajar siswa pada tindakan penelitian ini mencapai $85,71 \%$. Perubahan terjadi pada aspek kognitif, psikomotor, dan afektif selama dan/atau setelah mengalami proses belajar, yang ditunjukkan pada tabel-tabel hasil belajar, aktivitas, dan sikap tersebut di atas.

Peningkatan hasil belajar siswa dan kemampuan guru yang semakin baik dalam menerapkan model PBL berbantuan media pembelajaran ternyata bersifat linier positif. Perubahan perlakuan guru dalam membentuk dan/atau membagi kelompok-kelompok diskusi dan penataan tempat serta posisi duduk siswa pada tindakan siklus II telah meningkatkan sikap dan aktivitas siswa. Motivasi, apresiasi, dan penjelasan mengenai materi ajar oleh guru pada awal pertemuan membuahkan hasil yang baik. Pemilihan dan penanyangan media pembelajaran yang lebih konkret (sesuai dengan kenyataan) memberi kemudahan kepada siswa untuk memahami, menganalisis dan mengevaluasi materi ajar pada tindakan siklus II.

Aspek psikomotor. Aktivitas siswa dalam kelompok diskusi, diskusi kelas, dan kemampuan berfikir kritis -mengajukan pertanyaan dan menjawab- mengalami kemajuan positif. Selama perlakuan tindakan pertama, sebagaian besar siswa dalam pembelajaran kurang mampu menguasai materi ajar dan bekerja sama dalam kelompok diskusi. Kelompok diskusi yang dibentuk berdasarkan kelompok piket harian ternyata kurang baik sebagai sarana berinteraksi dan berkomunikasi antar-siswa. Hal ini terjadi karena siswa tidak biasa belajar kelompok, kurangnya pengarahan dan penjelasan guru mengenai pentingnya kerja sama dan koordinasi dalam kelompok diskusi berkaitan dengan kemampuan interpersonal siswa. Kemampuan interpersonal dalam kelompok sebagai bentuk dasar keahlian yang perlu dikembangkan pada diri siswa di lingkungan kelas/sekolah.

Aspek afeksi. Siswa kelas VIII C secara umum menerima dan menghargai pembelajaran model PBL berbantuan media. Siswa merespon dan mengapresiasi terhadap tahapan-tahapan pembelajaran model PBL dengan baik. Setiap arahan dan bimbingan yang dilakukan guru ditindaklanjuti dengan sikap dan perilaku yang sesuai. Pada proses pembentukan kelompok siswa tidak menolak/meminta teman duduknya dalam kelompok yang sama termasuk pemilihan atau penetapan materi diskusi, dan pembagian tugastugas kelompok. Sebagian besar siswa menerima dan menanggapi materi ajar, media pembelajaran, dan penjelasan/ulasan guru mengenai pertanyaan dan jawaban pada setiap akhir sesi diskusi.

\section{Simpulan dan Saran}

Simpulan

Berdasarkan hasil penelitian pada tindakan siklus I sampai dengan akhir tindakan siklus II dapat disimpulkan bahwa; (1) Penerapan pembelajaran model PBL berbantuan media gambar-diam dapat meningkatkan hasil belajar siswa secara komprehensif yang meliputi ranah kognitif, psikomotorik, dan afektif. Hasil belajar, aktivitas, dan sikap siswa pada setiap siklus menunjukkan adanya perubahan yang semakin baik. Hasil belajar pada tindakan siklus I dengan nilai tertinggi, terendah, dan rata-rata sebesar 87 , 53, dan 69 meningkat menjadi 93, 67, dan 77 pada siklus II. Sedangkan standar devisiasi nilai hasil belajar pada siklus I dan siklus II sebesar 9,73 dan 7,79. Ketuntasan belajar klasikal meningkat dari $60,00 \%$ menjadi $85,71 \%$. (2) Penerapan pembelajaran model PBL berbantuan media gambar-diam dapat meningkatkan aktivitas siswa selama pembelajaran. Peningkatan aktivitas siswa sebesar 0,36 dari rata-rata skor 3,01 
menjadi 3,37. Sedangkan sikap siswa terhadap pembelajaran mengalami peningkatan sebesar 5,77 dari 62,20 menjadi 67,97 pada siklus I dan siklus II. (3) Hasil belajar, aktivitas, dan sikap siswa pada setiap siklus menunjukkan adanya perubahan yang semakin baik. Hasil belajar pada tindakan siklus I dengan nilai tertinggi, terendah, dan rata-rata sebesar 87, 53, dan 69 meningkat menjadi 93, 67, dan 77 pada siklus II. Sedangkan standar devisiasi nilai hasil belajar pada siklus I dan siklus II sebesar 9,73 dan 7,79. Ketuntasan belajar klasikal meningkat dari $60,00 \%$ menjadi $85,71 \%$. (4) Penerapan pembelajaran model PBL berbantuan media gambar-diam dapat meningkatkan aktivitas siswa selama pembelajaran. Peningkatan aktivitas siswa sebesar 0,36 dari rata-rata skor 3,01 menjadi 3,37. Sedangkan sikap siswa terhadap pembelajaran mengalami peningkatan sebesar 5,77 dari 62,20 menjadi 67,97 pada siklus I dan siklus II.

\section{Saran}

Berdasarkan temuan hasil penelitian, pembelajaran model PBL berbentuan media dapat meningkatkan hasil dan aktivitas belajar terhadap mapel IPS pada siswa kelas VIII C SMP Negeri 2 Kawunganten Cilacap. Melangkah dari hal tersebut, dapat diajukan saran-saran sebagai berikut;

\section{Guru}

Guru dalam pelaksanaan pembelajaran dapat memilih model PBL dengan memperhatikan materi ajar dan perkembangan usia dan mental siswa.

Guru berusaha menerapkan pendekatan pembelajaran berpusat pada siswa (centred learner), pembelajaran mandiri -siswa menemukan masalah, mencari alternatif, menentukan solusi, dan mengungkapkan.

Guru beradaptasi dengan perkembangan teknologi informasi yang dapat diterapkan pada pembelajaran sebagai sumber/ materi ajar dan media pembelajaran untuk meningkatkan hasil belajar dan aktivitas siswa.

\section{Kepala Sekolah}

Memotivasi dan membina guru-guru menerapkan model-model pembelajaran khususnya model problem-based learning berbantuan media pembelajaran.

Meningkatkan pengadaan sarana atau media pembelajaran untuk terwujudnya pembelajaran yang efektif.

Memfasilitasi perijinan kepada guru, siswa dan/atau kelas melakukan observasi terhadap sumber belajar di luar lingkungan sekolah.

\section{Daftar Pustaka}

Amir, M T. (2013). Inovasi pendidikan melalui problem based learning: Bagaimana pendidik memberdayakan pemelajar di era pengetahuan. Jakarta: Predana Media Group.

Andreson, L.W., \& Krathwohl, D.R. (2010). Kerangka landasan untuk pembelajaran, pengajaran, dan assesmen, (edisi Revisi Taksonomi Pendidikan Bloom). Yogyakarata: Pustaka Pelajar.

Arends R.I. (2008). Learning to teach. Jilid I. Yogyakarta: Pustaka Pelajar. Judul asli "Learning to teach" (7th ed). New York: McGraw Hill Companies. (2007).

. (2008). Learning to teach. Jilid II. Yogyakarta: Pustaka Pelajar. Judul asli "Learning to teach" (7th ed). New York: McGraw Hill Companies. (2007).

(2010). Teaching for student learning. Yogyakarta: Pustaka Pelajar. New York: Library of Congress Cataloging in Publication Data.

Arsyad, A. (2002). Media pembelajaran. Jakarta: PT Raja Grafindo Persada.

Barth, J.L., (1984). Methodes of intruction in social studies education, (3rd ed). Lanham, Maryland: University Press of America.

Brock. S \& Jenkins.J. (2006). Problem Based Learning resource handbook. www.wlv. ac.uk/docs/soh-pbl.doc

Dimyati, \& Mudjiono. (2010). Belajar dan pembelajaran. Jakarta: DepDikBud. Co. Rineka Cipta.

Djamarah, S.B \& Zain, A. (2006). Strategi belajar-mengajar. (edisi revisi). Jakarta: Rineka Cipta.

Gafur, A. (2012). Desain pembelajaran konsep, model, dan aplikasinya dalam perencanaan pelaksanakan pembelajaran. Yogyakarta: Ombak. 
Gagne, R.M. (1988). Prinsip-prinsip belajar untuk pengajaran. Surabaya: Usana Offset Printing. Judul asli "Essentials of Learning for Instruction”. New York: Holf (1975).

Jarolimek, J. (1993). Social studies in elementary education $\left(9^{\text {th }} E d\right)$. New York:: Mac. Millan Publishing Company.

Johnson, A.P. (2010). Making connections in elementary and midlle school social studies. $\left(2^{\text {nd }} e d\right)$. New York: Library of Congess Cataloging in Publication Data.

Kemmis, S. \& Taggar, R Mc. (1990). The Action research planner. Victoria: Deakin University Press.

Martorella, P.H. (1994). Social studies for elementary school childen. developing young citizens. New York. Macmillan College Publishing Company, inc.

Rusman. (2012). Model-model pembelajaran: mengembangkan profesional guru. Jakarta: Rajawali.

Sanjaya, W. (2011). Strategi pembelajaran berorentasi strandar proses pendidikan. Jakarta: Kencana Prenada Media group.

Sardiman A.S. dkk. (2002). Media pendidikan: Pengertian, pengembangan, dan pemanfaatannya. Jakarta: Raja Grafido Persada.

Suleiman, A.H. (1985). Media audio-visual untuk pengajaran, penerangan, dan penyuluhan. Jakarta: Gramedia.

Trianto. (2010). Model pembelajaran terpadu: konsep, strategi, dan implementasinya dalam kurikulum tingkat satuan pendidikan (KTSP). Jakarta: Bumi Aksara.

Usman, M.U., \& Setiawati, L. (1993). Upaya optimalisasi kegiatan belajar mengajar. Bandung: Remaja Rosdakarya.

Warsita, B. (2008). Teknologi pembelajaran: Landasan dan aplikasinya. Jakarta: Rineka Cipta.

Warsono,dkk. (2012). Pembelajaran Aktif, Teori dan Asesmen. Bandung: PT Remaja Rosdakarya 